УДК 371.13./15:373.3

DOI:

Наталія Гречаник, кандидат педагогічних наук, доиент кафедри педагогіки і психології початкової освіти, докторант Глухівського національного педагогічного університету імені Олександра Довженка

\title{
КВІНТЕСЕНЦІЯ СКЛАДОВИХ КУЛЬТУРОЛОГІЧНОЇ ПІДГОТОВКИ МАЙБУТНЬОГО ВЧИТЕЛЯ ПОЧАТКОВОЇ ШКОЛИ
}

У статті розглянуто окремі складові культурологічної підготовки майбутніх вчителів початкових класів на засадах культурології. Окреслено структурні складові та визначені підструктури культурологічної підготовки, що в умовах сьогодення повинні відповідати спрямуванням соиіокультурного розвитку, а мета повинна бути орієнтиром для реалізації культурної функиії. Розкриваються сутнісні характеристики педагогічної культури вчителя при иьому розвиток його як творчої особистості має відбуватися в спеціально організованому культуро спрямованому середовищі.

Ключові слова: культурологічна підготовка; майбутній учитель; освіта; особистість; початкова школа; складова; иінності.

Puc. 1. Лim. 7.

Nataliya Hrechanyk, Ph.D.(Pedagogy), Associate Professor of the Primary Education Pedagogics and Psychology Department Doctoral student, Hlukhiv Oleksandr Dovzhenko National Pedagogical University

\section{THE QUINTESSENSE OF THE ELEMENTS FOR THE CULTURAL TRAINING OF FUTURE PRIMARY SCHOOL TEACHERS}

From the point of view of the culturological approach, the teacher, as a bearer of its systems, appears as a mechanism for the reproduction of culture and processes of personality cultural development. The educational level will be more effective, the more it will be integrated and fit into the context of culture.

Modern education is as streamlined and verbalized. It has lost its affectivity, emotional charge, until recently was inherent in childhood, and this is causing the existence of an increasing number of professional-competent, but spiritualless individuals. There is another group of reasons that point to the need to strengthen the culturological component of teacher training. They are conditioned by the fact that in the development of the world community in recent decades there has been an increasing priority of the "human, personal" in all spheres of life and education is no exception in this way. In this regard, it is a question of changing rationalism to the paradigm of cultural identity and cultural creation in education.

According to the above, the cultural element of pedagogical education at the present stage means the change of priority directions, where the center of mutual influence is the personality of the future teacher, the level of his culture, professionalism, and the knowledge, skills, abilities, which he possesses, should leave the educational plane, is understand as an end in itself and be transformed into means of his professional growth, self-actualization, self-improvement and formation, as an active subject in educational and sociocultural activity.

Thuse, cultural training provides for the formation of not just a teacher subject, but a specialist of a qualitatively new type - a teacher-culture study, teacher-researcher, who is able, using cultural-historical tools, in conjunction with the personal potential, to implement the acquired knowledge at a high professional level, to carry out pedagogical creativity and ensure the harmonious development and self-development of the personality of the younger schoolchild taking into account his individual abilities and potential abilities, which will enable the conceptual transition of the education system from a school of reproductive learning and memorization to a school of cultural development, thinking and action.

So we note that the concept of cultural training of the future primary school teacher is unfolding in the direction of constructive and global changes that are relevant of all post-industrial society.

Keywords: activities; an element; cultural training; a future teacher; an education; personality; a primary school; priority; society; values.

П остановка проблеми. Одним із найважливіших способів передачі новим поколінням накопичених людством знань та досвіду є освіта, що повинна допомогти сучасній людині побачити світ з позиції цінностей, осягнути своє буття, за яке несе відповідальність [3, 18]. Ї̈̈ зміст є одним 3 основних засобів розвитку особистості та формування iї базової культури. Навчання мови, історії вітчизни, літератури, принципам моралі й моральності служить передумовою для формування системи цінностей, завдяки яким 


\section{КВІНТЕСЕНЩІЯ СКЛАДОВИХ КУЛЬТУРОЛОГІЧНОЇ ПІДГОТОВКИ МАЙБУТНЬОГО ВЧИТЕЛЯ ПОЧАТКОВОЇ ШКОЛИ}

молодь навчається розуміти інших і самих себе, стає свідомою дієвою особою суспільства [2]. Вона набуває нової культуроцентруючої якості, а iï основними характеристиками стає самоцінність, зростаюча роль у формуванні людини культури, формування нових систем моральних цінностей, які б наближали людину до природи і соціуму [3, 20]. Донедавна зв'язок та взаємодія культури й педагогіки трактувалися з позицій трьох аспектів. Найбільш поширений - соціологічний, відповідно до якого освіта $є$ загальною формою культурноісторичного розвитку особистості та основою системи продукування та поширення духовних цінностей. Вузький: особистісна культура вчителя вивчалася в професійно-педагогічній площині, тобто стосувалася проблеми професійної культури. І вкрай звужений - аспекти педагогічної технології, методи, форми викладання, облаштування класів і кабінетів. Будь-який 3 означених підходів, на наш погляд, не стосується педагогічної культури, а отже, і методів їі формування та принципів розвитку. На думку вчених, культурологічна компетентність розглядається як сукупність знань про культуру в широкому та вузькому понятті цього слова, що дозволяє намалювати цілісну картину світу та показати значення навчальної дисципліни для уточнення цієї картини, яка дозволяє визначити місце людини в світі та способи зміни світу 3 урахуванням отриманих знань [7].

Відомо, коли одні люди почали відбирати, переробляти об'єкти культури 3 метою їх відтворення й залучати до цього інших людей, тоді виникла педагогічна діяльність, суть якої - в управлінні присвоєнням предметів культури. Таким чином, уже на ранніх етапах свого існування людство приходить до висновку, що культурологічне становлення особистості відбувається в процесі педагогічного впливу, тобто здійснюється педагогами $[1,35]$. Культурологізація освітньої царини є тією актуальною для педагогічної науки проблемою, що може розв'язуватися лише завдяки шанобливому ставленню до загальнолюдських цінностей, розумінню цілісності духовного, природного, соціального й культурологічних складових, що забезпечують розвиток світу й людства.

Сьогоднішні теоретичні інтереси педагогіки й психології підтверджують той емпірично доведений факт, що особистість та її самостійнодіяльнісне ставлення до світу вже перетнули межі теоретично-очікуваного конструкту й заявляють про себе в культурному житті як її вагомі складові. Основною метою культурологічної підготовки вчителя-початківця $€$ не сумарність знань й умінь, а оволодіння зразками людської культури й уміння передати цей культуротворчий досвід молодому поколінню.

Аналіз останніх досліджень і публікацій. Філософський компонент освіти як один зі складових культури обгрунтований в працях Г. Батіщева, І. Беха, І. Ільїної. Питання виховання 3 позицій культури висвітлюються в роботах С. Бондаревської, І. Зязюна, Н. Крилової, Н. Щуркової.

Корифеями психологічної науки Л. Виготським, О. Лурією, С. Рубінштейом та іншими досліджена залежність психічних властивостей індивіда від його соціокультурного оточення. Питання реалізації культурологічного підходу в теорії та практиці вищої школи обгрунтовано в працях Є. Баллера, С. Бондаревської, І.Зязюна, О. Рудницької, В. Сластьоніна та ін. Деякі аспекти культурологічної спрямованості підготовки майбутнього фахівця досліджуються у працях Л. Буєвої, І. Луцької,В. Маслова, О.Попової,Н. Сердюк. Обгрунтування засад культурологічного підходу в освіті (В. Андреєв, Г. Ващенко, В. Гриньова, I. Зязюн, Н. Крилова та ін.).

Дослідження та розуміння визначених концептуальних засад дасть змогу визначити категоріальний апарат нашого дослідження 3 позицій культурологічного підходу, реалізувати процес формування “людини культури”, яка має високий рівень загальної культури, культури професійного мислення, культури педагогічного спілкування, поведінки, мовленнєвої культури тощо [5, 198].

Мета статті - визначення й теоретичне осмислення проблем культурологічної підготовки майбутнього вчителя початкової школи в сучасних умовах.

Виклад основного матеріалу. Під складовими культурологічної підготовки майбутнього вчителя початкової школи ми розуміємо деякий обсяг знань, умінь і навичок культурологічного, психолого-педагогічного, філософського спрямування, що безпосередньо пов'язані із задоволенням професійних потреб учителя для виконання своєї культуростворюючої педагогічної діяльності.

Культурологічна підготовка вчителя інваріантно передбачає наступні специфічні складові: аксіологічну, когнітивну, процесуальну, управлінсько-регулятивну. Реєстр зазначених методологічних ознак дає підставу обгрунтувати майбутню модель культурологічної підготовки, складовими якої є означені складові (рис. 1).

Функціональне призначення складових культурологічної підготовки майбутнього вчителя полягає в наступному: 


\section{КВІНТЕСЕНЦЯ СКЛАДОВИХ КУЛЬТУРОЛОГІЧНОЇ ПДГОТОВКИ МАЙБУТНЬОГО ВЧИТЕЛЯ ПОЧАТКОВОЇ ШКОЛИ}

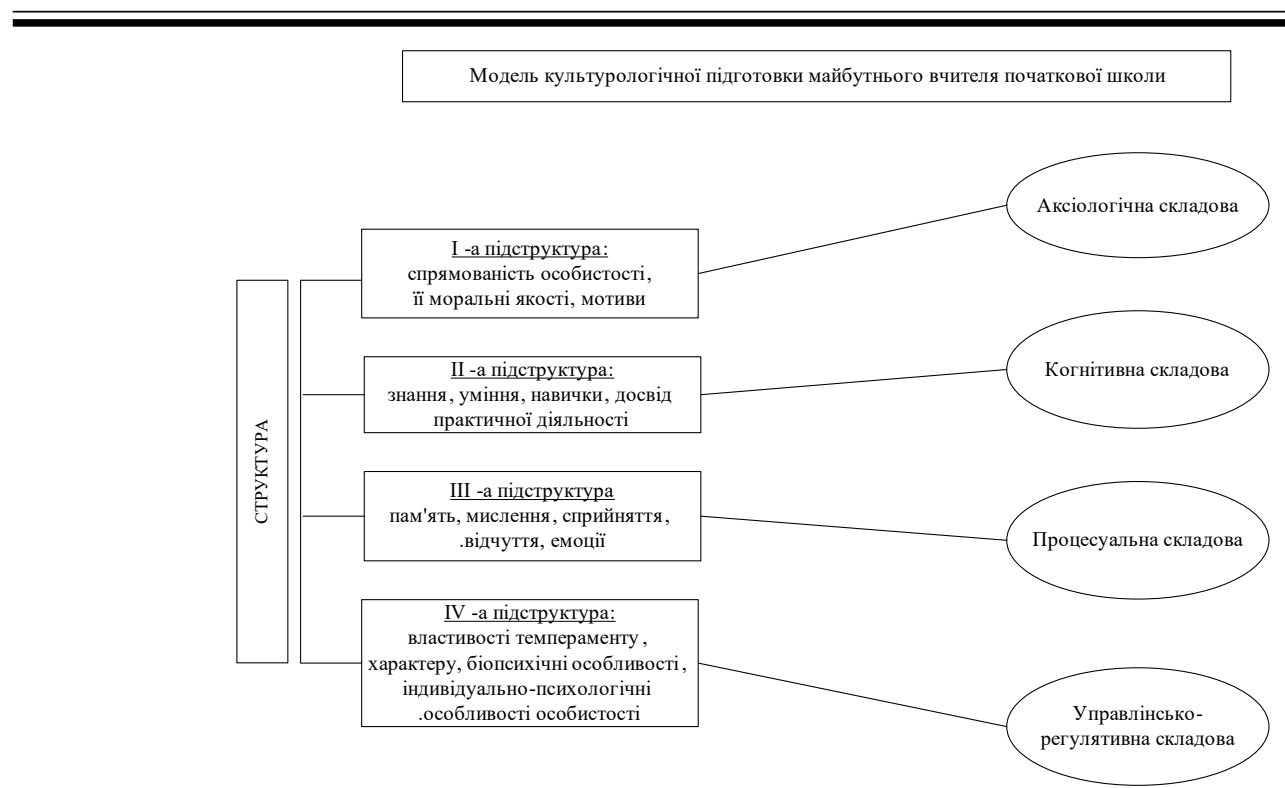

Рис. 1. Модель культурологічної підготовки майбутнього вчителя початкової школи

- аксіологічна складова пов'язана 3 розумінням смислових цінностей філософії культури й освіти. Діяльність учителя сьогодні має за орієнтир творче підгрунтя багатовекторного філософського й світоглядного надбання людства щодо того, що собою представляє людина 3 “глобальною свідомістю" з позиції педагогіки. Звідси випливає визначення місця вчителя як носія певної культури існування у світі, у соціумі, який включений у глобальні процеси трансформації Всесвіту. Досвід надбання культури не просто передається учнями через учителя, а й опосередкований його індивідуальністю, емоційноціннісними взаєминами, визначається не просто сумарністю відповідних соціально-особистісних позицій, а й фіксує певну світоглядну систему;

- когнітивна складова має прояв у таких іпостасях, як систематизація інформації, що визначається єдиною концептуальною основою, в єдності логічного змісту. Сднання категорій “освіта" й “інформація" є істотною ознакою, оскільки саме інформація може бути використана в освітній системі або системах як шлях маніпуляції індивідом або навпаки - як засіб, що забезпечує не тільки свободу дій, а й суб'єктивні прояви. Когнітивна складова передбачає наявність принципу історизму щодо оцінювання предметів і явищ дійсності. Когнітивна складова має прояв у функціях, що мають ознаки аналітичного характеру мислення, творчого підходу до досліджуваного знання, критичного підходу до сприйняття інформації;

- процесуальна складова забезпечує продукування нових педагогічних технологій, проектування культуронеобхідних засобів навчання, нестандартних творчих методик, вирішення теоретичних і практичних проблем, проектування нових цілей і педагогічних принципів. Нові педагогічні засоби, методи, прийоми дозволять вибрати альтернативні концепції культурологічної підготовки майбутнього вчителя.

- управлінсько-регулятивна складова регламентується психологічною культурою особистості майбутнього вчителя початкової школи, його саморозвитком, умінням і готовністю критично ставитися до процесів педагогічної реальності. Вона є запорукою адекватного реагування на ситуації, що відбуватимуться, зіставлення їх зовнішніх ознак зі своїми уявленнями про них, потребою і здатністю їх вирішення.

Зазначимо, що сукупність вищеозначених складових i опис їх функціонування не претендують на повний спектр характеристики процесу культурологічної підготовки майбутнього вчителя початкової школи. Кожен 3 них обумовлений відповідним структурним конструктом педагогічної свідомості вчителя, а також його особистісними орієнтаціями. Охарактеризуємо більш предметно.

Аксіологічна складова в культурологічній підготовці майбутнього вчителя визначається нами як пріоритетна, оскільки індивід постійно знаходиться в ситуації моральної, естетичної, світоглядної трансформації, що викликана зміною подій, ставленням до них суспільства, зміною оціночних суджень, постановки завдань, пошуком і прийняттям рішень щодо їх реалізації. Зміст усіх аспектів життєдіяльності визначається спрямованістю особистості на усвідомлення й актуалізацію загальнолюдських цінностей. Він 


\section{КВІНТЕСЕНЦІЯ СКЛАДОВИХ КУЛЬТУРОЛОГІЧНОЇПІДОТОВКИ МАЙБУТНЬОГО ВЧИТЕЛЯ ПОЧАТКОВОӤ ШКОЛИ}

забезпечує творчу складову змісту культурологічної підготовки. Процес освоєння й присвоєння вчителем напрацьованих педагогічних цінностей здійснюється на індивідуально-творчому рівні. Освоєння цінностей, що визначають педагогічну культуру, особистість здатна перетворювати, трансформувати, що продиктовано як особистісними характеристиками майбутнього вчителя, так і змістом його професійної науковопедагогічної діяльності. Це означає, що сучасний учитель - це творчий суб'єкт професійної педагогічної діяльності [6, 87].

Самовдосконалення таких якостей, як доброта, чесність, порядність, здатність відповідально вчиняти, толерантно ставитися до іншого, емпатійний стан, любов до дітей складають базовий рівень культурологічної підготовки майбутнього вчителя початкової школи. Саме тому в нашому дослідженні аксіологічна складова культури посідає особливе місце в процесі культурологічної підготовки.

Когнітивна складова має вираження в більш фундаментальних знаннях стосовно культури, процесів культурного розвитку соціуму та особистості, культурно-історичного досвіду свого народу. Когнітивною складовою культурологічного розвитку також визначається вивчення досвіду педагогів-новаторів, їх життєвого та творчого шляху. Проведений аналіз дає підстави стверджувати, що в умовах розвитку процесу соціокультурної діяльності в суспільстві тенденція до розвитку мінімуму культурологічного змісту педагогічної освіти зростає ще більше. Він повинен відображати вже досягнутий рівень розвитку культурологічних знань, тенденцію їх усвідомлення. Крім того, необхідно зробити особливий наголос на другій частині базової складової змісту культурологічної підготовки в системі педагогічної освіти, що виконує функціональну соціалізацію особистості майбутнього педагога, його духовний розвиток. Ця функція реалізується також через гуманітарні психолого-педагогічні дисципліни. Вони формують його як особистість, його загальну культуру, моральність, дозволяють реалізовувати потребу в інтелектуальному, культурному розвитку. Треба розглядати сучасні гуманізаційні можливості освіти, усвідомлюючи, що саме духовне, гуманістичне, людське й людяне є сутнісною основою в історії еволюції цивілізації, а відображення цих цінностей у системі природничо-наукового, фізико-математичного та соціогуманітарного знання $є$ засадою освітнього та педагогічного впливу на формування особистості $[4,46]$.
Когнітивна складова передбачає також цілепокладання, що фіксує траєкторії перспектив та проектів людської діяльності. У структурі духовного виробництва когнітивна складова забезпечує передусім: а) генерацію нових знань, норм, цінносних орієнтацій і значень; б) їх накопичення, зберігання й трансляцію; в) відтворення духовного процесу через підтримку його наступності; г) комунікативний процес, що забезпечує взаємодію між суб' єктами діяльності, їх диференціацію ієдність; д) соціалізацію соціуму через створення конструкту взаємин, опосередкованих культурними компонентами.

Звичайно, до відтворення такого досвіду студенти готуються не тільки в процесі оволодіння культурологічними знаннями. Велике значення мають інші загальноосвітні та фахові дисципліни, середовище, соціум, у якому живе й діє майбутній учитель. Таким чином, при визначенні базових складових змісту культурологічної освіти в процесі підготовки майбутнього вчителя необхідно мати на увазі, що воно покликане одночасно враховувати як загальні, так і диференційовані цілі. Диференційовані цілі змісту культурологічної підготовки дозволяють повніше відобразити цільову орієнтацію кожного типу навчального закладу, створити оптимальні умови для задоволення інтересів, схильностей, розвитку індивідуального підходу до процесу формування професійної готовності майбутнього вчителя щодо професійної та культурологічної діяльності.

Процесуальна складова описуваної моделі передбачає готовність вчителя до професійного самовдосконалення. Знання передових педагогічних технологій, уміння їх творчо застосовувати у своїй педагогічній діяльності, здатність до педагогічної творчості, прогнозування власної педагогічної діяльності, знання основ педагогічної майстерності, яке передбачає і культуру мови, і педагогічну техніку, й елементи ораторського мистецтва - усе це істотно впливає на рівень професійно-педагогічної культури вчителя, його педагогічну діяльність. Ця складова культурологічної підготовки містить в собі також інструментарій педагогічної діяльності майбутнього вчителя, ціннісні орієнтації фахівця, досягнення педагогічної культури, що освоюються й культивуються особистістю в процесі діяльності, це підтверджує нерозривний зв'язок культури та діяльності.

Управлінсько-регулятивна складова культурологічної підготовки спрямованана оволодіння вчителем основ психологічної культури, яка полягає в готовності проводити ним психолого-педагогічні експерименти, оволодіння методами та формами 


\section{КВІНТЕСЕНЩЯ СКЛАДОВИХ КУЛЬТУРОЛОГІЧНОЇПІДОТОВКИ}

МАЙБУТНЬОГО ВЧИТЕЛЯ ПОЧАТКОВОЇ ШКОЛИ

психологічного дослідження, пізнання самого себе як особистості й пізнання інших. Це також знання й психологічних мотивів, які обумовлюють той чи інший тип поведінки особистості, знання основ конфліктології.

Як суб'єкт соціокультурного розвитку майбутній учитель в результаті культурологічної підготовки має відповідати наступними критеріальним і рівневим характеристикам:

1) мати діапазон професійного педагогічного мислення, що забезпечується практичною діяльністю, а також категоріально-понятійним і концептуальним апаратом;

2) вільно орієнтуватися в галузі навчального предмета та мати відповідний рівень володіння ним; мати здатність до трансформування змісту предмета в діяльнісно-комунікативній формі;

3) розвивати мотивацію та прагнення до практичної реалізації у різних педагогічних функціях з метою повного забезпечення їх обсягу;

4) володіти сучасними педагогічними технологіями, реалізувати інтелектуальнорозвивальну, особистісно-формувальну функції, розвивати здатність до педагогічного аналізу, проектування, спроможності в експертній діяльності;

5) використовувати дослідницький, творчий ресурси, які є в наявності;

6) прагнути до саморозвитку.

Опис базових складових культурологічної підготовки майбутнього вчителя дають змогу розглянути це явище 3 боку статичної та динамічної наявності, з позиції сумарності індивідуально-професійних якостей, як цілісного системного утворення, яким $\epsilon$ культура. Пояснення розвитку особистості під кутом соціокультурного феномена розглядається нами як умова або передумова здійснення ефективного культурологічного функціонування, як синтез показника педагогічної культури, як мета його професійного та особистісного самовдосконалення.

Наша методологічна позиція при організації культурологічного підходу в базовій підготовці майбутнього вчителя полягає в тому, що вся сукупність як професійних, так і культурноціннісних якостей розглядається як система різних форм і рівнів суб'єктивного відображення й усвідомлення майбутнім учителем своєї культурологічної підготовки.

Чим глибше об'єктивно в майбутнього вчителя-початківця бачення особливостей свого соціокультурного розвитку, тим багатограннішим $\epsilon$ інструментарій для використання та вдосконалення не тільки своєї педагогічної культури, а й соціокультурного розвитку в цілому.
Уявлення майбутнім фахівцем ареалу свого соціокультурного розвитку, його утворювальних компонентів дозволяє йому під час власного професійно-педагогічного вдосконалення конструювати адекватний імідж “свого Я” і на цьому підгрунті науково вибудовувати персональну професійну Я-концепцію.

Висновки. Отже, у результаті теоретикопрактичних розвідок змісту базових складових культурологічної підготовки майбутніх вчителів початкової школи ми прийшли до наступних висновків:

- культурологічна підготовка - це універсум, що характеризує педагогічну реальність і має прояв у різних формах існування;

- культурологічна підготовка є складовою особистісної загальної культури фахівця, що специфічно проектує функцію загальної культури в сферу педагогічного практичного застосування;

- культурологічна підготовка розглядається нами з позиції системного утворення, що включає в себе ряд структурно-функціональних складових і має власну організацію, частково взаємодіє 3 навколишнім середовищем, наявністю властивостей інтегративного цілого, але при цьому не зводиться до домінування окремих частин;

- зразком аналізу культурологічної підготовки виступає педагогічна діяльність, що є творчою за своєю суттю;

- особливість реалізації та організація процесу культурологічної підготовки майбутнього фахівця обумовлюються індивідуально-творчою, психофізіологічною, віковою характеристиками, а також соціально-педагогічним досвідом особистості, що буде формуватися в процесі професійної діяльності.

Таким чином, вищеозначені складові, що регламентують специфічні вектори культурологічної підготовки майбутнього вчителя та $є$ елементами розглянутої моделі з позицій системного підходу, $\epsilon$ результатом соціокультурної траєкторії в розвитку його особистості, певною мірою патерном функціонування в культурологічній царині.

\section{ЛІТЕРАТУРА}

1. Бенин В. Л. Педагогическая культура: философско-социологический анализ. Уфа, 1997. $178 \mathrm{c}$.

2. Зюзіна Т. О. Компаративний аналіз проблеми визначення цілей и завдання гуманітарної культурологічної освіти: збірник наукових праць Бердянського державного педагогічного університету (педагогічні науки). №4. Бердянськ, 2006. 224 c. 
3. Зязюн І. Життєвий поступ людини у вимірі наукової і культурологічної парадигм / Педагогічна майстерність як система професійних i мистецьких компетентностей: зб. мат. VI мист.пед. читань пам'яті проф. О. Рудницької. Чернівці, 2010. C.15-24.

4. Касьянов Д. Філософські засади гуманізації освітнього простору в умовах нанотехнологічного розвитку суспільства / Вища освіта України. 2012. № 2. C. 43-49.

5. Ковальчук Л., Коник М. Культурологічна спрямованість як ознака високого рівня професіоналізму викладача вищої школи. Львів: Вісник Львів. ун-ту, 2009. Вип. 25. Ч. 1. С. 197-205.

6. Кравченко-Дзондза О. Е. Компетентнісна парадигма підготовки майбутнього вчителя початкової школи. Молодь і ринок. 2017. № 10 (153). C. 84-90.

7. Панкратова О. М. Культурологічна компетентність вчителів і iï формування. URL: file:///C:/Users/1/ Downloads/ pier.ulstu.ru /seminar/ archive/ 29 report.dok. (дата звернення: 19.12.2019).

\section{REFERENCES}

1. Benin, V. L. (1997). Pedagogicheskaya kultura: filosofsko-sotsiologicheskiy analiz [Pedagogical culture: philosophical and sociological analysis]. Ufa, 178 p. [in Russian].

2. Ziuzina, T. O. (2006). Komparatyvnyi analiz problemy vyznachennia tsilei y zavdannia humanitarnoi kulturolohichnoi osvity: zbirnyk naukovykh prats Berdianskoho derzhavnoho pedahohichnoho universytetu (pedahohichni nauky) [Comparative analysis of the problem of defining purpose and mission of humanitarian culturological education: collection of scientific works of Berdiansk State Pedagogical University (pedagogical sciences)]. No.4. Berdiansk, $24 \mathrm{p}$. [in Ukrainian].
3. Ziaziun, I. (2010). Zhyttievyi postup liudyny u vymiri naukovoi i kulturolohichnoi paradyhm [Life progress of people in measuring scientific and culturological paradigms]. Pedahohichna maisternist yak systema profesiinykh i mystetskykh kompetentnostei: zb. mat. VI myst.-ped. chytan pamiati prof. O. Rudnytskoi - Pedagogical skills as a system of professional and artistic qualities: collected mat. VI artificial and pedagogical readings in memory of Prof. A. Rudnitskoi. Chernivtsi, pp.1524. [in Ukrainian].

4. Kasianov, D.(2012). Filosofski zasady humanizatsii osvitnoho prostoru $\mathrm{v}$ umovakh nanotekhnolohichnoho rozvytku suspilstva [Philosophical foundations of humanization of educational space in the conditions of nanotechnological development of society]. Higher education of Ukraine. No. 2 pp. 43-49. [in Ukrainian].

5. Kovalchuk, L.\& Konyk, M. (2009). Kulturolohichna spriamovanistyak oznakavysokohorivnia profesionalizmu vykladacha vyshchoi shkoly [Cultural orientation as a sign of the high level of professional of the higher school teacher]. Lviv, Vol. 25. part. 1. pp. 197-205. [in Ukrainian].

6. Kravchenko-Dzondza, O. (2017). Kompetentnisna paradyhma pidhotovky maibutnoho vchytelia pochatkovoi shkoly [Competency paradigm of the preparation of the future teacher of elementary school]. Youth and market: Monthly scientific and pedagogical journal. Vol.10 (153). Drohobych, pp. 84-90. [in Ukrainian].

7. Pankratova, O. (2015). Kulturolohichna kompetentnist vchyteliv i yii formuvannia [Cultural competence of teachers and its formation]. Available at: file:///C:/Users/1/Downloads/ pier.ulstu.ru / seminar/ archive/ 29 report.dok. (accessed 19 Dec. 2019). [in Ukrainian].

Стаття надійшла до редакції 05.11.2019

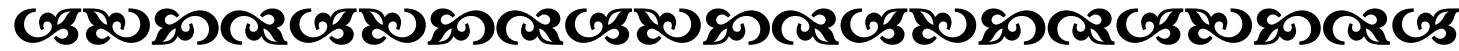

"Знання - не інертний, пасивний відвідувач, який приходить до нас, хочемо ми цього чи ні; його потрібно шуқати, перш ніжвоно буде нашим; воно - результат великої роботи і тому-великої жертви".

Тенрі Боқхи

англійський історик $і$ соиіолог

"ТТри шляхи ведуть до знання: шлях роздумів - ие шлях найблагородніший, шлях наслідування - це шлях найлегший $і$ шлях досвіду - це шлях самий гірқий”.

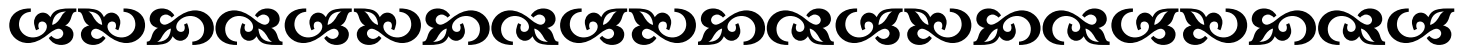

